\title{
The Impact of the Attitudes towards Ecotourism Benefits on Destination Loyalty
}

\author{
Ibrahim Bazazo ${ }^{1}$, Mohammed Abdullah Nasseef ${ }^{2}$, Abderrahman Al-Zawaideh ${ }^{1}$, Ali Al-Zawaideh ${ }^{1} \&$ Mahmoud \\ Al-Dhomaidat ${ }^{1}$ \\ ${ }^{1}$ Department of Tourism Management, Faculty of Tourism and Hospitality, The University of Jordan, Aqaba, Jordan \\ ${ }^{2}$ Department of Business Administration, Faculty of Economics and Administration, King Abdulaziz University, \\ Jeddah, Saudi Arabia \\ Correspondence: Ibrahim Bazazo, Department of Tourism Management, Faculty of Tourism and Hospitality, The \\ University of Jordan, Aqaba, Jordan. Tel: 962-3-209-0450. E-mail: i.bazazo@ju.edu.jo
}

Received: June 15, 2017

Accepted: June 22, 2017

Online Published: June 27, 2017

doi:10.5430/jms.v8n3p67

URL: https://doi.org/10.5430/jms.v8n3p67

\begin{abstract}
This study aims to examine the impact of attitudes towards ecotourism benefits (using the variables of economic development, social development, cultural preservation, community capacity building, and environmental protection) on destination loyalty of Wadi-Rum located in Jordan. A total of 297 questionnaire containing 29 items was used to collect information from the local residents of Wadi-Rum. Simple regression, T-test, and ANOVA analyses were conducted to test the research hypotheses. Results of the current study revealed that there is a significant positive impact of attitudes towards ecotourism benefits on destination loyalty. Also, the results revealed that there is no significant difference in the impact of attitudes towards ecotourism benefits on destination loyalty that can be attributed to gender. In addition, results found there is no significant difference in the impact of attitudes towards ecotourism benefits on destination loyalty in favor of age, and educational level.
\end{abstract}

Keywords: ecotourism, destination loyalty, Arab world, Jordan

\section{Introduction}

The world is witnessing today attention and care evident in the concept of environmental and sustainable tourism that will provide clean distinctive environment free of any visitor beside disabled person as could lead to a change in the concept of sustainability in various fields. The concept of environmental and sustainable tourism development has led to attract tourists in large numbers in the various regions of the world to the intended tourist environment had, which have been characterized by the presence of awareness by the government and the local community towards the good care, planning, marketing and promotion for that destination, which would make all responsible parties are aware of what will happen as a result of any work that may be done by one of the users and visitors to the area (Su et al., 2014). The ultimate objective of most of the world is to make the intended environmental areas of the province as it was from the customs and traditions and the promotion of the local economy and work to upgrade environmental attractions to sustain all areas associated with this concept. Ecotourism is a form of tourism that involves visiting natural areas fragile, pristine and relatively without hindrance. Its purpose is to educate the traveler may be, to provide the necessary funds for protecting the environment; to directly benefit the economic development and political empowerment of local communities, or to promote respect for different cultures and human rights. Since 1980, ecotourism has been considered a decisive effort for the environment; so that future generations to confront the circumstances affecting them through human intervention. Several university programs use this description as in the definition of ecotourism work (Wu et al., 2015).

Generally, ecotourism dealing with the living parts of natural environments, and focuses on socially responsible travel, as well as personal growth and environmental sustainability. Ecotourism usually include travel to destinations where the flora and fauna, as well as the cultural heritage of the main attractions. It is intended that, that ecotourism provide insight into the impact of humans on the environment, and promote a greater appreciation of the natural habitats, including ecotourism is responsible for minimizing the negative aspects of conventional tourism on the environment programs, in addition to strengthening the cultural unity of the local population and evaluation of environmental factors. Hence we address to tackle Wadi Rum in Jordan. It is so hard to describe the beauty of Wadi Rum, but it is 
breathtaking. It is one of the most important tourist sites in Jordan. Know the area colored Rocky Mountains yellow and white and red and brown and geographic characteristic shapes filled with color and deep valley, which cleaves the mountains. Land of Wadi Rum and are also characterized by natural bridges and rocks that take the forms of Mushrooms, naturally carved by wind and erosion factors and erosion over the years (Jordanian Ministry of Tourism and Antiquities).

Featuring Wadi Rum plant life and animal unique and rare. The focus was on animal life in Wadi Rum after it was discovered the existence of the gray wolves, deer and foxes from a platoon "Blandford" rare red foxes and cats dunes. There are also many rare plants and herbs. And anemones grow red anemone flowers on the sides of the road and in the quietest places. You can also find in some mountainous areas and some medicinal herbs used by the Bedouins of hospitalization for several centuries. Play numerous nomadic tribes that inhabit the Wadi Rum area an important role in the beauty of the area is complete, even though some of them now live in a modern concrete houses; however, the majority still wear Bedouin outfit and adheres to the nomadic tradition by living a nomadic way such as raising the beauty and to drink milk and sew from goat hair tents throughout the summer. Many lovers of hiking are attracted to Wadi Rum, and enjoy climbing mountains and dramatic, with a height of some of the 1754 meters. And one of the most beautiful places of climbing Mount Khazali and Jebel Rum. The hikers the rookie, you can enjoy an easy stroll between the colored and dry or desert sand dunes and rocky plateaus (Jordanian Ministry of Tourism and Antiquities). Indeed, the Declaration and the Wadi Rum area in 1998 protected area. It has been appointed the Royal Society for the Protection of Nature with support from the World Bank, a non-profit organization based on the preparation of plans to preserve and protect the region in addition to the formation of a team of local administration for the region on their own. This team is working under the auspices of the authority of the Aqaba Special Economic Zone and is devising ways to protect and preserve the Wadi Rum desert from the pressures of the growing human. It can be played discoveries and adventures inside and outside these protected, depending on the type of activity to be done.

The rest of this paper is organized as follows. The hypotheses development and research model are described. It then presents the methodology used for the study followed by its analysis and findings. The discussion and conclusion are then provided and areas for future research are also addressed.

\section{Hypotheses Development}

According to the study accomplished by Akbarzadeh and his colleagues (2011) where this research was conducted to find and use the best sites on environmental tourism development. This has been done through the adoption of an ecosystem approach to environmental issues, and the use of geographic information systems in the regions of Arasbarn area in Iran. Several issues focused on providing best practices and the status of the study area used maps by the Iranian geographical organization, which has been one of the materials and methods used in this research as well as their dependence ways avoiding ecological and environmental fabricated tools. According to study of Neba (2009), the reserves and other areas vitelline, serves as the fields and the expected environmental development of tourism in order to contain their biodiversity and the landscape and cultural heritage of local or indigenous people. She has been using a sample of a game reserve in Kimbi environmental sustainability to game reserves. She conducted ecotourism development process by employing a range of field observation to data collection and evaluation, and it is done by SWOT analysis technique; where identifies opportunities and threats. The use of the reserve data base to draw data on wildlife resources and systems methodology which includes rural appraisal, where she worked as a methodology to assess the current situation for wildlife, as well as field observations unofficial.

According to study of Gezon (2009), which focused on the theme of ecotourism in the regions of Medkhr and Ankara, and this has increased the interest in early research, so that was in 1990, it has been associated with it in the donor in the field of conservation and ecotourism. He used a qualitative approach; as this analysis focuses on the social level intensify the effects of tourism, comparing and contrasting communities on any side of the protected area. Also, it increased the number of tourists and infrastructure to accommodate. He developed them and guiding professional tour. In the process, this study was based on ethnographic research conducted between 1989 and 2010 in Ankarana region of Madagascar. According to study of Dorobantu et al. (2012), which focused on the important factor of economic activity in the European Union, which is composed of a wide range of products and destinations and many different stakeholders? The study adopted important topics environmental such as tourism, local communities, rural tourism, and sustainable development in Romania.

According to study of Su et al. (2014), which focused on the development of ecotourism, is closely associated with the sustainability of the natural protected areas, where facilitated by appropriate management; ecotourism can contribute to the conservation and development. In addition, it works on the welfare of the community. It has focused on the presence of a positive synergy between tourism and the environment on the one hand and society on the other. 
Researchers can also develop this relationship, planning, and can discuss public policy for the development of ecotourism requirements in protected areas in China. This study has focused on the ecotourism assess, stakeholders and community participation in Xingkai Lake National Reserve in China. According to study of Wu et al. (2015), which focused on eight criteria: slope, tourism attraction, the density of the drainage system, cover the pastures, cover plants, the community, the height and density of the road network. All this is to assess the ecotourism in China Nature Reserve. This study has focused on ecotourism, assessing their suitability and preference for ecotourism in Hijnyang Chinese.

Barkauskiene \& Snieska (2013), focused on ecotourism analysis as an integral part of the sustainable development of tourism. This study provides ecotourism as one of the fastest-growing types of tourism in the world. The study focused on important topics such as tourism, environment, sustainable tourism, sustainable tourism development and system analysis SWOT in Lithuania. According to study of Adrian Mendosa Ramos \& Bruce Prieaux (2014), which focused on receiving the original ecotourism in the Mayan rainforest, little research got attention. This study deals with issues related to the level of empowerment in the Mayan village, which is located near the heritage sites in the south of Mexico. This study has focused on the original ecotourism, in addition to enabling stakeholders in the Mayan rainforest in Mexico. According to study of Blerseh \& Kangas (2013), which focused to the emergence of ecotourism in the past two decades as an important strategy for the province, especially in the tropics; where the terms of the diversity of species and habitats threatened traditional forms of development. Further, it has focused on the study subject's important ecological Kalnzm model ecotourism to save the tropical ecosystem in Blize.

In order to test the research model of the impact of attitudes towards ecotourism benefits on destination loyalty, the study is hypothesized as follows:

H1: There is a statistically significant impact of attitudes towards ecotourism benefits on destination loyalty.

H2A: There is a significant difference in the impact of attitudes towards ecotourism benefits on destination loyalty due to gender.

H2B: There is a significant difference in the impact of attitudes towards ecotourism benefits on destination loyalty due to age.

H2C: There is a significant difference in the impact of attitudes towards ecotourism benefits on destination loyalty due to educational level.

\section{Research Methodology}

This section provides the methodology applied in the current study. It consists of the research model, operational definitions of the study's independent and dependent variables, research hypotheses, besides data collection tool and research population and sample.

\subsection{Research Model}

The elements of this research are established based on preceding literature, either theoretically or empirically. Indeed, this study used variables that are common in ecotourism literature. Figure 1 represents a model for the study that shows the relationship between the research independent variable, the dependent variable, and the moderating ones. 


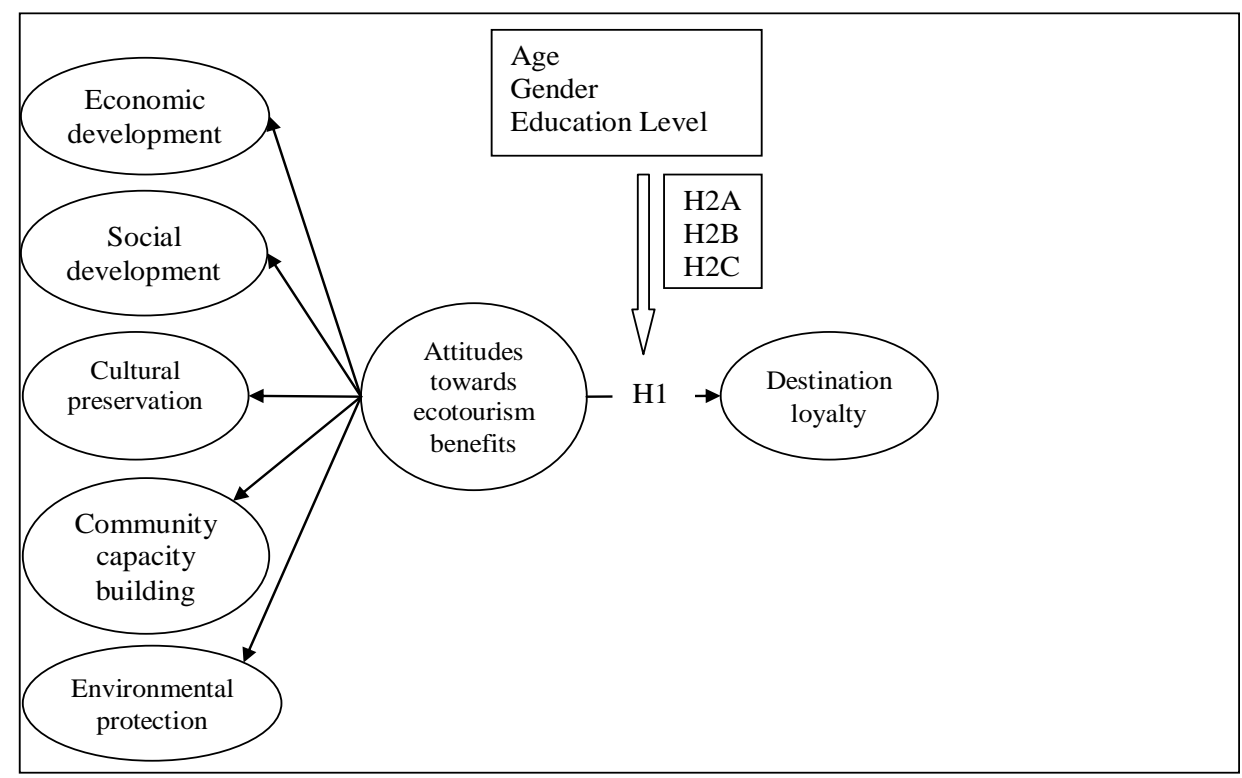

Figure 1. Research Model

\subsection{Operational Definitions}

Adapted from Chengcai et al. (2012), the current research considers five attitudes towards ecotourism benefits (the independent variable). These dimensions are economic development, social development, cultural preservation, community capacity building, and environmental protection; which were measured in the research questionnaire through three, eleven, three, five, and two items respectively. Also, destination loyalty, the dependent variable, adapted from Rahman (2014) and measured through five items.

\subsection{Population and Sampling}

This study has been the target of local residents of Wadi Rum categories; it has been ranked based on the age structure in addition to the educational level. A total of 297 questionnaire containing 29 items was used to collect information from the local residents of Wadi-Rum.

\section{Data Analysis and Results}

In order to explore the impact of attitudes towards ecotourism benefits on destination loyalty, in which these variables have been measured using 5 -points Likert scale that varies between strongly disagree $=1$ and strongly agree $=5$; reliability and validity analyses were conducted, descriptive analysis was used to describe the characteristic of sample and the respondent to the questionnaires besides the independent and dependent variables. Also, simple regression analysis, Independent Samples T-test, and ANOVA test were employed to test the research hypotheses.

\subsection{Validity and Reliability}

Validity and reliability are two important measures to determine the quality and usefulness of the primary data. Validity is about accuracy and whether the instrument measures what it is intended to measure while reliability is about precision; it is used to check the consistency and stability of the questionnaire. Indeed, the researchers depended on scales and items that were previously developed and used by other researchers with similar interest. Also a draft of the questionnaire was formulated, and then it was reviewed by four academic lecturers -who have a sufficient knowledge and experience in this scope- to insure that each item is measuring what is intended to be measured, and to avoid the ambiguity and complexity in the phrasing of questions. The reliability of the instrument was measured by the Cronbach's alpha coefficient. Further, some scholars (e.g. Bagozzi \& Yi, 1988; Creswell, 2009) suggested that the values of all indicators or dimensional scales should be above the recommended value of 0.60. Table 1 represents the results of Cranach's alpha for the independent and dependent variables. Cronbach's alpha coefficients of all the tested variables are above 0.60 which suggesting the composite measure is reliable. 
Table 1. The Cronbach's alpha coefficients of study variables

\begin{tabular}{lcc}
\hline Variables & Number of items & Cronbach alpha \\
\hline Economic development & 3 & 0.683 \\
\hline Social development & 11 & 0.782 \\
\hline Cultural preservation & 3 & 0.653 \\
\hline Community capacity building & 5 & 0.770 \\
\hline Environmental protection & 2 & 0.636 \\
\hline Destination loyalty & 5 & 0.863 \\
\hline
\end{tabular}

\subsection{Respondents Demographic Profile}

As indicated in Table 2, the demographic profile of the respondents for this study showed that they are typically females, most of them less than 30 years old, and the majorities less than high school and hold high school degree.

Table 2. Description of the respondents' demographic profiles

\begin{tabular}{lccc}
\hline Category & Category & Frequency & Percentage\% \\
\hline Gender & Males & 141 & 47.5 \\
\cline { 2 - 4 } & Females & 156 & 52.5 \\
\cline { 2 - 4 } Age & Total & 297 & 100 \\
\cline { 2 - 4 } & less than 20 & 105 & 35.4 \\
\cline { 2 - 4 } & 20 years - less than 25 & 95 & 32.0 \\
\cline { 2 - 4 } & 25 years - less than 30 & 44 & 14.8 \\
\cline { 2 - 4 } & 30 years - less than 40 & 28 & 9.4 \\
\cline { 2 - 4 } & More than 40 years old & 25 & 8.4 \\
\hline Education level & Total & 297 & 100 \\
\cline { 2 - 4 } & Less than high school & 84 & 28.3 \\
\cline { 2 - 4 } & High school & 132 & 44.4 \\
\cline { 2 - 4 } & Diploma & 39 & 13.2 \\
\cline { 2 - 4 } & Bachelor & 25 & 5.4 \\
\cline { 2 - 4 } & Master & 16 & 100 \\
\cline { 2 - 4 } & Doctorate & 297 & \\
\cline { 2 - 4 } & Total & & 5.3 \\
\hline
\end{tabular}

\subsection{Descriptive Analysis}

In order to describe the responses and thus the attitude of the respondents toward each question they were asked in the survey, the mean and the standard deviation were estimated. While the mean shows the central tendency of the data, the standard deviation measures the dispersion which offers an index of the spread or variability in the data (Pallant, 2005; Sekaran \& Bougie, 2013). In other words, a small standard deviation for a set of values reveals that these values are clustered closely about the mean or located close to it; a large standard deviation indicates the opposite. The level of each item was determined by the following formula: (highest point in Likert scale - lowest point in Likert scale) / the number of the levels used $=(5-1) / 5=0.80$, where 1-1.80 reflected by "very low", 1.81-2.60 reflected by "low", 2.61-3.40 reflected by "moderate", 3.41-4.20 reflected by "high", and 4.21-5 reflected by "very high". Then the items were being ordered based on their means. Tables 3 and 4 show the results. 
Table 3. Overall mean and standard deviation of the study's variables

\begin{tabular}{clcccc}
\hline $\begin{array}{c}\text { Type of } \\
\text { Variable }\end{array}$ & Variables & Mean & Standard Deviation & Level & Order \\
\hline $\begin{array}{c}\text { Independent } \\
\text { Variables }\end{array}$ & Attitudes towards ecotourism benefits & 3.80 & 0.68 & High & \\
\hline & Economic development & 3.99 & 0.74 & High & 2 \\
\hline & Social development & 3.47 & 0.62 & High & 5 \\
\hline & Cultural preservation & 3.73 & 0.71 & High & 3 \\
\hline & Community capacity building & 3.72 & 0.81 & High & 4 \\
\hline $\begin{array}{c}\text { Dependent } \\
\text { Variable }\end{array}$ & Environmental protection & 4.10 & 0.79 & High & 1 \\
\hline
\end{tabular}

As presented in Table 3, data analysis results have shown that residents' attitudes towards ecotourism benefits in Wadi-Rum are applied to a high level in which the mean score is 3.80. Further, environmental protection, economic development, cultural preservation, community capacity building, and social development do exist highly and respectively; besides destination loyalty is applied to a greater extent. Table 4 demonstrates the mean, standard deviation, level, and order scores for resident attitudes towards ecotourism benefits items for each variable.

Table 4. Mean and standard deviation of the study's variables

\begin{tabular}{lcccc}
\hline Economic development & Mean & SD & Level & Order \\
\hline Ecotourism promotes local economic development & 4.02 & 0.94 & High & 1 \\
\hline Ecotourism promotes local industry development & 3.94 & 0.92 & High & 2 \\
\hline Ecotourism increases the income of local residents & 4.02 & 0.97 & High & 1 \\
\hline Social development & Mean & SD & Level & Order \\
\hline Ecotourism increases employment opportunities for local residents & 3.95 & 0.90 & High & 3 \\
\hline Ecotourism increases employment opportunities for local female residents & 3.28 & 1.32 & Moderate & 7 \\
\hline Ecotourism raises local fame & 4.09 & 0.89 & High & 1 \\
\hline Ecotourism facilitates the exchange of local and outside & 4.00 & 0.91 & High & 2 \\
\hline Ecotourism promotes national unity & 3.61 & 0.95 & High & 5 \\
\hline Ecotourism improves local infrastructure & 3.53 & 1.00 & High & 6 \\
\hline Ecotourism improves local quality of life & 3.72 & 1.07 & High & 4 \\
\hline Ecotourism sharpens the polarization between the rich and the poor & 3.08 & 1.32 & Moderate & 8 \\
residents (Reversed) & & & & \\
\hline Ecotourism increases the price and the cost of living (Reversed) & 2.96 & 1.28 & Moderate & 9 \\
\hline Ecotourism disrupts daily lives for residents (Reversed) & 2.54 & 1.31 & Low & 11 \\
\hline Ecotourism leads to local traffic congestion (Reversed) & 2.61 & 1.31 & Moderate & 10 \\
\hline Cultural preservation & Mean & SD & Level & Order \\
\hline Ecotourism promotes protection on local cultural heritage & 3.99 & 0.99 & High & 1 \\
\hline Ecotourism promotes protection on the diversity of local cultural activities & 3.91 & 0.90 & High & 2 \\
\hline Ecotourism destroys local Wadi-rum culture & 3.29 & 1.35 & Moderate & 3 \\
\hline Community capacity building & Mean & SD & Level & Order \\
\hline Ecotourism enhances the cohesion of community & 3.68 & 1.17 & High & 4 \\
\hline Ecotourism improves the ability and quality of local residents & 3.78 & 0.97 & High & 1 \\
\hline $\begin{array}{l}\text { Ecotourism contributes to the rehabilitation and training of the local } \\
\text { community (courses, training programs) }\end{array}$ & 3.71 & 1.18 & High & 3 \\
\hline & & & & \\
\end{tabular}




\begin{tabular}{lcccc}
\hline $\begin{array}{l}\text { Ecotourism has contributes to increasing the contribution of the local } \\
\text { community through their participation in decision-making }\end{array}$ & 3.71 & 1.16 & High & 3 \\
\hline Local tourism contributes to increase in the number of local organizations & 3.77 & 1.08 & High & 2 \\
\hline Environmental protection & Mean & SD & Level & Order \\
\hline Ecotourism protects and improve local natural environment & 4.05 & 0.99 & High & 2 \\
\hline Ecotourism improves local residents' awareness on protection environment & 4.15 & 0.864 & High & 1 \\
\hline Destination loyalty & Mean & SD & Level & Order \\
\hline I think tourists will return to Wadi-rum in the future & 4.32 & 0.84 & Very high & 4 \\
\hline $\begin{array}{l}\text { I think tourists are willing to recommend Wadi-rum to family and friends } \\
\text { as a holiday destination }\end{array}$ & 4.36 & 0.86 & Very high & 2 \\
\hline I think tourists have wonderful image of Wadi-rum as a holiday destination & 4.33 & 0.89 & Very high & 3 \\
\hline I think tourists are very loyal to Wadi-rum as a destination choice & 4.26 & 0.91 & Very high & 5 \\
\hline $\begin{array}{l}\text { I think tourists will return to the same destinations that they previously } \\
\text { visited in Wadi-rum }\end{array}$ & 4.47 & 0.85 & Very high & 1 \\
\hline & & & & \\
\hline
\end{tabular}

\subsection{Hypotheses Testing Results}

The current research is mainly seeking to investigate the impact of resident attitudes towards ecotourism benefits on destination loyalty in Wadi-Rum in Jordan. Consequently, in order to test the main hypothesis developed for this study, a simple regression technique was used as demonstrated in Table 5.

Table 5. Regression analysis: Destination loyalty as dependent variable

\begin{tabular}{crrrrrrr}
\hline \multicolumn{1}{c}{ Dependent variable } & $\mathrm{r}$ & $\mathbf{R}^{2}$ & $\mathrm{f}$ & $\mathbf{S i g}(\mathbf{f})$ & $\boldsymbol{\beta}$ & $\mathrm{t}$ & Sig (t) \\
\hline Destination loyalty & 0.633 & 0.400 & 141.993 & $0.000 \mathrm{a}$ & 0.353 & 6.476 & $0.000 \mathrm{~b}$ \\
\hline
\end{tabular}

a. Predictors: (Constant), Attitudes towards ecotourism benefits

b. Dependent variable: Destination loyalty

Refer to Table 5 the correlation coefficient $\mathrm{R}=0.633$ indicates that there is a positive correlation between attitudes towards ecotourism benefits and destination loyalty. The R2 indicated the generalizability of the model. It allows us to generalize the results taken from the respondents to the whole population. In this case it equals 0.400 . The results showed that F-ratio for these data is equal to 141.993 , which is statistically significant at $\mathrm{p}<0.05$. Therefore, we conclude that there is a statistically significant effect of attitudes towards ecotourism benefits on destination loyalty. The $\beta$ indicates the contribution of the predictor (i.e. the independent variable) to the model. Table 5 shows the standardized coefficients for the attitudes towards ecotourism benefits. The value of $\beta$ is 0.353 , which does have a significant effect on destination loyalty.

Hypotheses $\mathrm{H} 2 \mathrm{~A}, \mathrm{H} 2 \mathrm{~B}$, and $\mathrm{H} 2 \mathrm{C}$ argued that there is a significant difference in the impact of attitudes towards ecotourism benefits on destination loyalty due to gender, age, and educational level. Independent Samples T-test was employed in order to investigate if there any significant differences in the impact of attitudes towards ecotourism benefits on destination loyalty that can be attributed to gender. Also, ANOVA test was employed to examine if there any significant differences in the impact of attitudes towards ecotourism benefits on destination loyalty that can be attributed to age, and educational level. Results of T-test, shown in Table 6, indicated that there is no significant difference in the impact of attitudes towards ecotourism benefits on destination loyalty that can be attributed to gender. Also, results of ANOVA test, shown in Table 7, and Table 8, indicated that there is no significant difference in the impact of attitudes towards ecotourism benefits on destination loyalty in favor of age, and educational level. 
Table 6. T-test of resident attitudes towards ecotourism benefits on destination loyalty due to gender

\begin{tabular}{lcccccccccc}
\hline & \multicolumn{4}{c}{ Male } & \multicolumn{3}{c}{ Female } & T & df & Sig. \\
\cline { 2 - 10 } \multicolumn{1}{c}{ Variables } & $\mathbf{N}$ & Mean & Std. Dev. & N & Mean & Std. Dev. & & & \\
\hline Destination loyalty & 141 & 4.3560 & 0.65251 & 156 & 4.3410 & 0.74564 & 0.185 & 294.700 & 0.853 \\
\hline
\end{tabular}

Table 7. ANOVA Analysis of resident attitudes towards ecotourism benefits on destination loyalty to age

\begin{tabular}{ccccccc}
\hline Variables & \multicolumn{1}{c}{$\begin{array}{c}\text { Sum of } \\
\text { Squares }\end{array}$} & Df & $\begin{array}{c}\text { Mean } \\
\text { Square }\end{array}$ & F & Sig. \\
\hline Destination loyalty & $\begin{array}{c}\text { Between } \\
\text { Groups }\end{array}$ & 3.477 & 4 & 0.869 & 1.783 & 0.132 \\
\cline { 2 - 4 } & $\begin{array}{c}\text { Within } \\
\text { Groups }\end{array}$ & 142.325 & 292 & 0.487 & & \\
\cline { 2 - 4 } & Total & 145.801 & 296 & &
\end{tabular}

Table 8. ANOVA Analysis of attitudes towards ecotourism benefits on destination loyalty due to educational level

\begin{tabular}{ccccccc}
\hline Variables & \multicolumn{1}{c}{$\begin{array}{c}\text { Sum of } \\
\text { Squares }\end{array}$} & Df & $\begin{array}{c}\text { Mean } \\
\text { Square }\end{array}$ & F & Sig. \\
\hline Destination loyalty & $\begin{array}{c}\text { Between } \\
\text { Groups }\end{array}$ & 3.949 & 5 & 0.790 & 1.620 & 0.155 \\
\cline { 2 - 5 } & $\begin{array}{c}\text { Within } \\
\text { Groups }\end{array}$ & 141.853 & 291 & 0.487 & & \\
\cline { 2 - 7 } & Total & 145.801 & 296 & &
\end{tabular}

\section{Discussion and Conclusions}

Through the case study of Wadi Rum in Jordan and the extent of the environmental impact of tourism and the vulnerability of the various emergency situations from several aspects, found that tourism is a social activity that involves travel on an individual or group aims to stay outside their usual environment over a period not too long; for the purpose of entertainment and business or other purposes. The development of sustainable rural tourism and responsible achievable without the application of the concept environmental thinking. As a result; help ecotourism and naturally on the development of tourism in rural areas. In order to do the natural ecotourism activities, we need to implement the management plans that contribute well to ensure professionalism, training, organization professional improvement for operators and that proper regulation of tourist flows. We need to determine the support for each threshold the protected area through management plans and that the integration of conservation issues and protection of natural and cultural environment with economic issues.

The emergence of the demographic character of the respondents to this study, mostly were females, most of whom are age less than 30 years, and the majority between less than high school and hold a high school diploma. This was with regard to demographic matters. Results of the descriptive analysis which showed determine the level of each of the following formula: (highest point Likert scale - the lowest point in the Likert) / number of levels used = scale (5.1) / 5 $=0.80$, where 1 to 1.80 , which reflected "very low", from 1.81 to 2.60 , which reflected a "low", from 2.61 to 3.40 , which reflected a "moderate", from 3.41 to 4.20 , which reflected the "high", and from 4.21 to 5 reflected "very high". And then going on the items ordered according to their means. The emergence of the level of the resident population towards ecotourism benefits for each variable, and found to be at a high level, which was the result of 3.85, and that was for the protection of the environment, economic development, cultural preservation, community capacity building and social development.

The current research seeks primarily to achieve the effect of resident positions in order to take advantage of ecotourism 
that helps the loyalty tourist destination in Wadi Rum in Jordan. Further research is needed in other areas to validate the research model. Also, more research should consider the role of Information Technology (IT) in enhancing the ecotourism reachability. Indeed, several researchers consider the information systems and in particular the IT and its flexibility as an enabler to achieve the desired competitive advantages, and as a crucial support to operational and strategic business decisions (Al Azmi et al., 2012; Alenezi et al., 2015; Alkalha et al., 2012; Almajali \& Tarhini, 2016; Altamony et al., 2012; Kateb et al., 2015; Maqableh \& Karajeh, 2014a, 2014b; Masa'deh, 2012, 2013a, 2013b; Masa'deh et al., 2016; Obeidat et al., 2013; Shannak et al., 2010, 2012a, 2012b; Tarhini et al., 2016; Vratskikh et al., 2016); thus further research is required to examine the role of such IT applications in enhancing the managerial decisions. In addition, scholars (e.g. Masa'deh et al. 2008; Hunaiti et al., 2009; Masa'deh \& Kuk, 2009; Alshurideh et al., 2012; Hajir et al., 2015; Kannan \& Gharibeh, 2013; Masa'deh \& Shannak, 2012; Masa'deh et al. 2013; Masa'deh et al. 2015a, 2015b, 2015c; Masa'deh et al. 2017; Obeidat et al., 2012, 2016; Shannak \& Alkour, 2012; Tarhini et al., 2015a, 2015b) emphasize the need for large firms to integrate their IT systems with their KM strategies and processes in order to survive in their highly competitive business environments, which in turn could accelerate the managerial decisions as well.

\section{References}

Abbasi, M. S., Elyas, T., \& Shah, F. (2015). Impact of individualism and collectivism over the individual's technology acceptance behaviour: A multi-group analysis between Pakistan and Turkey. Journal of Enterprise Information Management, 28(6), 747-768. https://doi.org/10.1108/JEIM-12-2014-0124

Akbarzadeh, M., Kafaki, S., Shahrokhi, S., \& Kouhgardi, E. (2011). Environmental Evaluation for Ecotourism Development using GIS in Arasbaran Area, Iran. International Conference on Asia Agriculture and Animal IPCBEE, 13, IACSIT Press, Singapore.

Al Azmi, N., Al-Lozi, M., Al-Zu'bi, Z., Dahiyat, S., \& Masa'deh, R. (2012). Patients Attitudes toward Service Quality and its Impact on their Satisfaction in Physical Therapy in KSA Hospitals. European Journal of Social Sciences, 34(2), 300-314.

Al-Badi, A., Tarhini, A., \& Al-Kaaf, W. (2017). Financial Incentives for Adopting Cloud Computing in Higher Educational Institutions. Asian Social Science, 13(4), 162-174. https://doi.org/10.5539/ass.v13n4p162

Al-Badi, A., Tarhini, A., \& Al-Sawaei, S. (2017). Utilizing Social Media to Encourage Domestic Tourism in Oman. International Journal of Business and Management, 12(4), 84-94. https://doi.org/10.5539/ijbm.v12n4p84

Al-Badi, A. H., \& Al-Qayoudhi, W. S. (2014). Adoption of social networks in business: Study of users and potential users in Oman. The International Business \& Economics Research Journal (Online), 13(2), 401-415. https://doi.org/10.19030/iber.v13i2.8457

Al-Dmour, H., Al-Madani, S., Alansari, I., \& Al-Dmour, R. (2016). Factors Affecting the Effectiveness of Cause-Related Marketing Campaign: Moderating Effect of Sponsor-Cause Congruence. International Journal of Marketing Studies, 8(5), 114-127. https://doi.org/10.5539/ijms.v8n5p114

Al-Dmour, R., \& Obeidat, B. (2015). Strategic IT-Business Alignment as Managers' Explorative and Exploitative Strategies. European Scientific Journal, 11(7), 437-457.

Alenezi, H., Masa'deh, R. Alalwan, A., \& Al-Qirim, N. (2017). Factors Affecting e-Government Adoption in Kuwait: A Qualitative study. Electronic Journal of e-Government, 15(2), 84-102.

Alenezi, H., Tarhini, A., \& Masa'deh, R. (2015). Investigating the Strategic Relationship between Information Quality and E-Government Benefits: A Literature Review. International Review of Social Sciences and Humanities, 9(1), 33-50.

Alkalha, Z., Al-Zu'bi, Z., Al-Dmour, H., \& Alshurideh, M. (2012). Investigating the Effects of Human Resource Policies on Organizational Performance: An Empirical Study on Commercial Banks Operating in Jordan. European Journal of Economics, Finance and Administrative Sciences, 51, 44-64.

Allam, M., \& Elyas, T. (2016). Perceptions of Using Social Media as an ELT Tool among EFL Teachers in the Saudi Context. English Language Teaching, 9(7), 1-9. https://doi.org/10.5539/elt.v9n7p1

Almajali, D., \& Tarhini, A. (2016). Antecedents of ERP Systems Implementation Success: A Study on Jordanian Healthcare Sector. Journal of Enterprise Information Management, 29(4), 549-565. https://doi.org/10.1108/JEIM-03-2015-0024

Al-Qirim, M., Rouibah, K., Serhani, M. A., Yammahi, A. R., \& Yammahi, M. A. (2017). Towards a Personality 
Understanding of Information Technology Students and their IT Learning in UAE University. Education and Information Technologies, 1-12. https://doi.org/10.1007/s10639-017-9578-1

Al-Qirim, N., Rouibah, K., Serhani, M. A., Yammahi, A. R. \& Yammahi, M. A. (2017). Learning Orientations of IT Higher Education Students in UAE University. Education and Information Technologies, 1-14. https://doi.org/10.1007/s10639-017-9589-y

Al-Qirim N., Tarhini, A., Rouibah, K. (2017). Determinants of Big Data Adoption and Success. In International Conference on Communications and Future Internet (ICCFI 2017). Jeju Island, South Korea, 10-13 August.

Alqahtani, M. A., Al-Badi, A. H., \& Mayhew, P. J. (2012). The Enablers and Disablers of E-Commerce: Consumers' Perspectives. The Electronic Journal of Information Systems in Developing Countries, 54(1), 1-25.

Alrowwad, A., Obeidat, B.Y., \& Aqqad, N. (2017). The impact of transformational leadership on organizational performance via the mediating role of corporate social responsibility: A structural equation modeling approach. International Business Research, 10(1), 199-221. https://doi.org/10.5539/ibr.v10n1p199

Alshurideh, M., Masa'deh, R., \& Alkurdi, B. (2012). The Effect of Customer Satisfaction on Customer Retention in the Jordanian Mobile Market: An Empirical Investigation. European Journal of Economics, Finance and Administrative Sciences, 47, 69-78.

Altamony, H., Alshurideh, M., \& Obeidat, B. (2012). Information Systems for Competitive Advantage: Implementation of an Organizational Strategic Management Process. Proceedings of the 18th IBIMA Conference on Innovation and Sustainable Economic Competitive Advantage: From Regional Development to World Economic, Istanbul, Turkey, 9th-10th May.

Altamony, H., Al-Salti, Z., Gharaibeh, A., \& Elyas, T. (2016). The relationship between Change Management Strategy and Successful Enterprise Resource Planning (ERP) Implementations: A Theoretical Perspective. International Journal of Business Management and Economic Research, 7(4), 690-703.

Bagozzi, R., \& Yi, Y. (1988). On the Evaluation of Structural Evaluation Models. Journal of the Academy of Marketing Science, 16(1), 74-94. https://doi.org/10.1007/BF02723327

Barkauskiene, K., \& Snieska, V. (2013). Ecotourism as an Integralpart of Sustainable Tourism Development. Economic and Management, 18(3), 449-456. https://doi.org/10.5755/j01.em.18.3.4272

Bisharat, H., Obeidat, B.Y., Alrowwad, A., \& Mukattash, I. (2017). The Effect of Human Resource Management Practices on Organizational Commitment in Chain Pharmacies in Jordan. International Journal of Business and Management, 12(1), 50-67. https://doi.org/10.5539/ijbm.v12n1p50

Blerseh, D., \& Kangas, P. (2013). A Modeling Analysis of the Sustainability of Ecotourism in Belize. Environment, Development and Sustainability, 15(1), 67-80. https://doi.org/10.1007/s10668-012-9374-4

Chengcai, T., Linsheng, Z., \& Shengkui, C. (2012). Tibetan Attitudes towards Community Participation and $\begin{array}{lllll}\text { Ecotourism. Journal of Resources and } & \text { Ecology, }\end{array}$ https://doi.org/10.5814/j.issn.1674-764x.2012.01.002

Creswell, J. (2009). Research Design: Qualitative, Quantitative, and Mixed Methods Approaches (3rd ed.). Thousand Oaks: Sage Publications.

Dorobantu, M., Nistoreanu, P., \& Puiu, N. (2012). Rural Tourism and Ecotourism the Main Priorities in Sustainable Development Orientations of Rural Local Communities in Romania. Economy Transdisciplinarity Cognition, 1, 259-266.

El-Masri, M., \& Tarhini, A. (2015). A Design Science Approach to Gamify Education: From Games to Platforms. Twenty-Third European Conference on Information Systems (ECIS), Münster, Germany. 26-29 May 2015.

El-Masri, M., \& Tarhini, A. (2017). Factors affecting the adoption of e-learning systems in Qatar and USA: Extending the Unified Theory of Acceptance and Use of Technology 2 (UTAUT2). Educational Technology Research and Development, 65(3), 743-763. https://doi.org/10.1007/s11423-016-9508-8

El-Masri, M., Orozco, J., Tarhini, A., \& Tarhini, T. (2015). The Impact of IS-Business Alignment Practices on Organizational Choice of IS-Business Alignment Strategies. The 19th Pacific Asia Conference on Information Systems (PACIS 2015), Paper 215, Singapore, 6-9 July 2015.

Elyas, T., \& Picard, P. (2012). Teaching and Moral Tradition in Saudi Arabia: A Paradigm of Struggle or Pathway towards Globalization?. Procedia - Social and Behavioral Sciences, 41, 1083-1086. 
https://doi.org/10.1016/j.sbspro.2012.06.782

Fedai, L., Daglı, G., Altınay, Z., \& Altınay, F. (2017). The examination of occupational burnout and job satisfaction of the physical education teachers. International Journal of Economic Perspectives, 11(1), 12-26.

Gezon, L (2009). Who Wins and Who Loses? Unpacking the "Local People" Concept in Ecotourism: A Longitudinal Study of Community Equity in Ankarana, Madagascar. Journal of Sustainable Tourism, 22(5), 821-838. https://doi.org/10.1080/09669582.2013.847942

Hajir, J., Obeidat, B., \& Al-dalahmeh, M. (2015). The Role of Knowledge Management Infrastructure in Enhancing Innovation at Mobile Telecommunication Companies in Jordan. European Journal of Social Sciences, 50(3), 313-330.

Hamoud, M., Akour, M. A., \& Al-Salti, Z. (2016). Developing the Main Knowledge Management Process via Social Media in the IT Organisations: A Conceptual Perspective. International Journal of Business Administration, 7(5), 49-64.

Hassouna, M., Elyas, T., \& Abou Trab, M. S. (2015). Customer Churn in Mobile Markets: A Comparison of Techniques. International Business Research, 8(6), 224-237. https://doi.org/10.5539/ibr.v8n6p224

Hussian, A., Elyas, T., \& Nasseef, O. (2013). Research Paradigms: A Slippery Slope for Fresh Researchers. Life Science Journal, 10(4), 2374-2381.

Hunaiti, Z., Mansour, M., \& Al-Nawafleh, A. (2009). Electronic Commerce Adoption Barriers in Small and Medium-Sized Enterprises (SMEs) in Developing Countries: The Case of Libya. IBIMA Business Review, 2(5), $37-45$.

Jordanian Ministry of Tourism and Antiquities. Retrieved from http://www.mota.gov.jo

Kanaan, R., \& Gharibeh, A. (2013). The Impact of Knowledge Sharing Enablers on Knowledge Sharing Capability: An Empirical Study on Jordanian Telecommunication Firms. European Scientific Journal, 9(22), 237-258.

Kateb, M., Swies, R., Obeidat, B., \& Maqableh, M. (2015). An Investigation on the Critical Factors of Information System Implementation in Jordanian Information Technology Companies. European Journal of Business and Management, 7(36), 11-28.

Mahadeen, B., Al-Dmour, R., \& Obeidat, B. Y. (2016). Examining the effect of the Organization's Internal Control System on Organizational Effectiveness: A Jordanian empirical study. International Journal of Business Administration, 7(6), 22-41. https://doi.org/10.5430/ijba.v7n6p22

Maqableh, M., \& Karajeh, H. (2014a). Job Scheduling for Cloud Computing Using Neural Networks. Communications and Network, 6(3), 191. https://doi.org/10.4236/cn.2014.63021

Maqableh, M., \& Karajeh, H. (2014b). A Theoretical Perspective on the Relationship between Leadership Development, Knowledge Management Capability, and Firm Performance. Asian Social Science, 10(6), 128.

Masa'deh, R. (2013). The Impact of Information Technology Infrastructure Flexibility on Firm Performance: An Empirical Study of Jordanian Public Shareholding Firms. Jordan Journal of Business Administration, 204-224. https://doi.org/10.12816/0002054

Masa'deh, R., \& Kuk, G. (2009). Antecedents and Intermediaries between Strategic Alignment and Firm Performance. Conference of the Academy of Management Annual Meeting (AOM), Illinois, Chicago, USA.

Masa'deh, R., Gharaibeh, A., Maqableh, M., \& Karajeh, H. (2013a). An Empirical Study of Antecedents and Outcomes of Knowledge Sharing Capability in Jordanian Telecommunication Firms: A Structural Equation Modeling Approach. Life Science Journal, 10(4), 2284-2296.

Masa'deh, R., Hunaiti, Z., \& Bani Yaseen, A. (2008). An Integrative Model Linking IT-Business Strategic Alignment and Firm Performance: The Mediating Role of Pursuing Innovation and Knowledge Management Strategies. Communications of the International Business Information Management Association (IBIMA) Journal, 2(24), 180-187.

Masa'deh, R., Shannak, R., \& Maqableh, M. (2013b). A Structural Equation Modeling Approach for Determining Antecedents and Outcomes of Students' Attitude toward Mobile Commerce Adoption. Life Science Journal, $10(4), 2321-2333$.

Masa'deh, R., Tayeh, M., Al-Jarrah, I., \& Tarhini, A. (2015c). Accounting vs. Market-based Measures of Firm Performance Related to Information Technology Investments. International Review of Social Sciences and 
Humanities, 129-145.

Masa'deh, R. (2012). The Impact of Management Information Systems (MIS) on Quality Assurance (QA): A Case Study in Jordan. International Journal of Information, Business, and Management, 93-110.

Masa'deh, R., \& Shannak, R. (2012). Intermediary Effects of Knowledge Management Strategy and Learning Orientation on Strategic Alignment and Firm Performance. Research Journal of International Studies, 112-128.

Masa'deh, R., Gharaibeh, A., \& Obeidat, O. (2015a). Knowledge Sharing Capability: A Literature Review. In Fourth Scientific \& Research Conference on New Trends in Business, Management and Social Sciences, Istanbul, Turkey, 19-20 September 2015 (pp. 1-16). https://doi.org/10.2139/ssrn.2696924

Masa'deh, R., Obeidat, B., \& Al-Dmour, R. (2015b). Knowledge Management Strategies as Intermediary Variables between IT-Business Strategic Alignment and Firm Performance. European Scientific Journal, 11(7), $344-368$.

Masa'deh, R., Obeidat, B., \& Tarhini, A. (2016). A Jordanian Empirical Study of the Associations among Transformational Leadership, Transactional Leadership, Knowledge Sharing, Job Performance, and Firm Performance: A Structural Equation Modelling Approach. Journal of Management Development, 35(5), 681-705. https://doi.org/10.1108/JMD-09-2015-0134

Masa'deh, R., Shannak, R., \& Maqableh, M., (2017). The Impact of Knowledge Management on Job Performance in Higher Education: The Case of the University of Jordan. Journal of Enterprise Information Management, 30(2), 244-262. https://doi.org/10.1108/JEIM-09-2015-0087

Neba, N (2009). Ecological Planning and Ecotourism Development in Kimbi. Game Reserve, Cameroon. Journal of Human Ecology, 27(2), 105-113.

Nassar, B., \& Arzoky, M. (2015). An Empirical Analysis of the Seasonal Patterns in Aggregate Directors' Trades. International Journal of Economics and Finance, 7(9), 59-84. https://doi.org/10.5539/ijef.v7n9p59

Obeidat, B. Y., Hashem, L., Alansari, I, \& Al-Salti, Z. (2016). The Effect of Knowledge Management Uses on Total Quality Management Practices: A Theoretical Perspective. Journal of Management and Strategy, 7(4), 18-29. https://doi.org/10.5430/jms.v7n4p18

Obeidat, B., Al-Suradi, M., \& Tarhini, A. (2016). The Impact of Knowledge Management on Innovation: An Empirical Study on Jordanian Consultancy Firms. Management Research Review, 39(10), 1214-1238. https://doi.org/10.1108/MRR-09-2015-0214

Obeidat, B., El-Rimawi, S., Maqableh, M., \& Al-Jarrah, I. (2013). Evaluating the Profitability of the Islamic Banks in Jordan. European Journal of Economics, Finance and Administrative Sciences, 56, 27-36.

Obeidat, B., Sweis, R., Zyod, D., \& Alshurideh, M. (2012). The Effect of Perceived Service Quality on Customer Loyalty in Internet Service Providers in Jordan. Journal of Management Research, 4(4), $224-242$. https://doi.org/10.5296/jmr.v4i4.2130

Obeidat, B.Y., Al-Sarayrah, S., Al-Salti, Z., \& Sweis, R. (2016). Cultural Influence on Strategic Human Resource Management Practices: A Jordanian case study. International Business Research, 9(10), 94-114. https://doi.org/10.5539/ibr.v9n10p94

Obeidat, B.Y., Tarhini, A., \& Aqqad, N. (2017). The impact of intellectual capital on innovation via the mediating role of knowledge management: A structural equation modeling approach. International Journal of Knowledge Management Studies, 8(2), 15-33.

Orozco, J., Tarhini, A., Masa'deh, R., \& Tarhini, T. (2015). A framework of IS/business alignment management practices to improve the design of IT Governance architectures. International Journal of Business and Management, 10(4), 1-12. https://doi.org/10.5539/ijbm.v10n4p1

Pallant, J. (2005). SPSS Survival Manual: A Step Guide to Data Analysis Using SPSS for Windows Version 12. Chicago, Illinois: Open University Press.

Rahman, M. (2014). Motivating Factors of Islamic Tourist's Destination Loyalty: An Empirical Investigation in Malaysia. Journal of Tourism and Hospitality Management, 2(1), 63-77.

Ramos, A., \& Prideaux, B. (2014). Indigenous Ecotourism in the Mayan Rainforest of Palenque: Empowerment Issues in Sustainable Development. Journal of Sustainable Tourism, 22(3), 461-479. https://doi.org/10.1080/09669582.2013.828730

Sekaran, U., \& Bougie, R. (2013). Research Methods for Business: A Skill Building Approach (6th ed.). New York: 
Wiley.

Shannak, R., \& Akour, M. (2012). Knowledge Management Strategy Building: Literature Review. European Scientific Journal, 8(15), 143-168.

Shannak, R., Al-Zu'bi, Z., Obeidat, B., Alshurideh, M., \& Altamony, H. (2012a). A Theoretical Perspective on the Relationship between Knowledge Management Systems, Customer Knowledge Management, and Firm Competitive Advantage. European Journal of Social Sciences, 32(4), 520-532.

Shannak, R., Obeidat, B., \& Almajali, D. (2010). Information Technology Investments: A Literature Review. Proceedings of the 14th IBIMA Conference on Global Business Transformation through Innovation and Knowledge Management: An Academic Perspective, Istanbul-Turkey, 23rd-24th June, pp.1356-1368.

Shannak, R., Obeidat, B., \& Masa'deh, R. (2012b). Culture and the Implementation Process of Strategic Decisions in Jordan. Journal of Management Research, 4(4), 257-281. https://doi.org/10.5296/jmr.v4i4.2160

Su, M., Wall, G., \& Ma, Z. (2014). Assessing Ecotourism from a Multi Stakeholder Perspective: Xingkai Lake National Nature Reserve, China, 1190-1207.

Tarhini, A., Al-Badi, A., Almajali, M., \& Alrabayaah, S. H. (2017). Factors influencing employees' Intention to use Cloud Computing. Journal of Management \& Strategy, 8(2), 47-62. https://doi.org/10.5430/jms.v8n2p47

Tarhini, A., Elyas, T., Akour, M. A., \& Al-Salti, Z. (2016). Technology, Demographic Characteristics and E-Learning Acceptance: A Conceptual Model Based on Extended Technology Acceptance Model. Higher Education Studies, 6(3), 72-89. https://doi.org/10.5539/hes.v6n3p72

Tarhini, A., El-Masri, M., Ali, M., \& Serrano, A. (2016). Extending the UTAUT model to understand the customers' acceptance and use of internet banking in Lebanon: A structural equation modeling approach. Information Technology and People, 29(4), 830-849. https://doi.org/10.1108/ITP-02-2014-0034

Tarhini, A., Arachchilage, N., \& Abbasi, M. (2015). A Critical Review of Theories and Models of Technology Adoption and Acceptance in Information System Research. International Journal of Technology Diffusion, 6(4), 58-77. https://doi.org/10.4018/IJTD.2015100104

Tarhini, A., Mgbemena, C., AbouTrab, M.S., \& Masa'deh, R. (2015). User Adoption of Online Banking in Nigeria: A Qualitative study. Journal of Internet Banking and Commerce, 20(3), 1-8.

Tarhini, A., Mohammed, A., \& Maqableh, M. (2016). Modeling Factors Affecting Student's Usage Behaviour of E-Learning Systems in Lebanon. International Journal of Business and Management, 11(2), $299-314$. https://doi.org/10.5539/ijbm.v11n2p299

Tarhini, A., Mohammed, A., \& Maqableh, M. (2016). Modeling Factors Affecting Student's Usage Behaviour of E-Learning Systems in Lebanon. International Journal of Business and Management, 11(2), 299. https://doi.org/10.5539/ijbm.v11n2p299

Vratskikh, I., Al-Lozi, M., \& Maqableh, M. (2016). The Impact of Emotional Intelligence on Job Performance via the Mediating Role of Job Satisfaction. International Journal of Business and Management, 10(5), 69-91. https://doi.org/10.5539/ijbm.v11n2p69

Wu, W., Zhang, X., Yang, Z., Qin, W., Wang, F., \& Wang, C. (2015). Ecotourism Suitability and Zoning from the Tourist Perspective: A Nature Reserve Case Study. Journal of Environmental Studies, 24(6), 2683-2697. https://doi.org/10.15244/pjoes/59422 